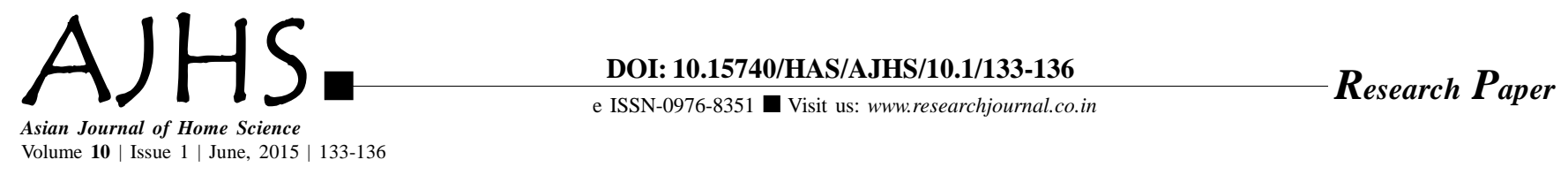

\title{
Prevalence of obesity among school going children of Pantnagar
}

\author{
SUMAN SINGH BAGHEL, NEETU DOBHAL AND RITA SINGH RAGHUVANSHI
}

Received: 03.02.2015; Revised: 07.04.2015; Accepted: 22.04.2015

See end of the paper for authors' affiliations SUMAN SINGH BAGHEL Department of Foods and Nutrition, College of Home Science, G.B. Pant University of Agriculture and Technology, Pantnagar, U.S. NAGAR (UTTARAKHAND) INDIA Email : ssb_3110@rediffmail.com
DABSTRACT : A cross sectional study was conducted to explore the prevalence of overweight/ obesity among the school going children of Pantnagar. The prevalence of obesity among the school going children was assessed by anthropometric measurements viz., height and weight, BMI and total body fat per cent. The overall prevalence of overweight was 16 and 4 per cent in HIG and MIG categories, respectively and prevalence obesity was reported in 3.8 per cent of HIG, The prevalence of overweight/obesity was higher in HIG children, which reflects the economical status on nutritional status.

KEY WORDS: School going children, BMI, Nutritional status, Obesity

口 HOW TO CITE THIS PAPER : Baghel, Suman Singh, Dobhal, Neetu and Raghuvanshi, Rita Singh (2015). Prevalence of obesity among school going children of Pantnagar. Asian J. Home Sci., 10 (1) : 133-136. 